\title{
PENGARUH KOMPETENSI, DISIPLIN KERJA, DAN LINGKUNGAN KERJA TERHADAP KINERJA KARYAWAN PADA HOTEL MAHARADJA
}

\author{
Hendri Jopanda \\ Dosen Tetap Program S1 Jurusan Manajemen Fakultas Ekonomi Universitas Satya Negara Indonesia \\ Email : hjopanda@yahoo.com
}

\begin{abstract}
This research aims to know the influence of competence, dicipline of work and environment of work on performance of employees on the Maharadja Hotel. Determining the research by using samples as much as 94 respondents and this research method by using multiple linear regression. This results show that the partially positive efffect and significant effect of competence against the performance of employees on the value of the Maharadja Hotel are $t_{\text {hitung }}>t_{\text {tabel }} 14.315>1.985$ and significant value are $0.000<0.05$ discipline of work influential positive effect and significantly to the performance of employees on the value of the Maharadja Hotel are $t_{\text {hitung }}>t_{\text {tabel }} 4.032>1.985$ and significant are $0.000<0.05$ and environment of work positive and significant effect on performance of employees on the value of the Maharadja Hotel are $t_{\text {hitung }}>t_{\text {tabel }} 5.007>1.985$ and significant are $0.000<0.05$ indicates that simultaneously while the competence, the discipline of work and environment of work on performance of employees on the value of the Maharadja Hotel are $F_{\text {hitung }}>F_{\text {abel }}>$ $106.533>2.70$ with a significant level of $0.000>0.05$.
\end{abstract}

Key words : competence, discipline of work, work environment, and performance of employees

\section{PENDAHULUAN}

Dalam upaya menghadapi persaingan diperlukan SDM yang mempunyai tingkat kinerja yang tinggi dengan lima unsur. Menurut Hasanuddin (2004) Sumber Daya meliputi 5M yaitu : Man, Materials, Machine, Methods, Money. Menurut Hasibuan (2017:9) unsur Man (manusia) ini berkembang menjadi suatu bidang ilmu manajemen yang disebut manajemen sumber daya manusia atau disingkat MSDM yang merupakan terjemahan dari man power management.

Sumber daya manusia merupakan asset yang harus ditingkatkan secara efektif dan efisien sehingga akan terwujud kinerja yang optimal karena mempengaruhi perilaku yang men jalankan organisasi. Untuk mencapai itu semua organisasi dalam hal ini perusahaan harus mampu menciptakan situasi dan kondisi yang mendorong dan memungkinkan karyawan untuk mengembangkan kemampuan dan keterampilan secara optimal, khususnya dalam hal kinerja.

Menurut Rivai (2012:541) faktor yang dapat mempengaruhi kinerja karyawan dapat digolongkaan menjadi tiga kelompok yaitu kompensasi individu, dukungan organisasi, faktor psikologis.

1. Kompensasi Individu

Kompensasi Individu adalah kemampuan dan keterampilan melalukan kerja. Kompensasi setiap orang dipengaruhi oleh beberapa faktor yang dapat dikelompokan menjadi 6 (enam) golongan yaitu :
a. Kemampuan dan keterampilan kerja
b. Keahlian
c. Kebutuhan
d. Tanggung jawab
e. Etos kerja 
2. Faktor Dukungan Organisasi

Kondisi dan syarat kerja setiap orang juga tergantung pada dukungan organisasi dalam bentuk pengorganisasian, penyediaan sarana dan prasarana kerja, kenyamanan lingkungan kerja serta kondisi dan syarat kerja. Pengorganisasian yang dimaksud disini adalah untuk memberikan kejelasan bagi setiap unit kerja dan setiap orang tentang sasaran tersebut.

3. Faktor Psikologis

Kinerja perusahaan dan kinerja perorangan juga sangat tergantung pada kemapuan psikologis seperti presepsi, sikap dan motivasi.

PT.Maharadja adalah perusahaan dibidang jasa atau service hotel. Dalam upaya mengelola SDM yang berkinerja tinggi melakukan perbaikan-perbaikan : kenaikan upah, fasilitas kesehatan, karir dan lain lain. Dari observasi yang peneliti lakukan pada PT.Maharadja menemukan data dan fakta bahwa frekuensi kunjungan pelanggan itu cendrung tidak stabil. Hal ini tidak maksimal karena sesuai dengan catatan peneliti yang diperoleh dari konsumen dimana beberapa komplain konsumen yang meliputi seperti Pelayannya kurang memuaskan, Resepsionis yang kurang komunikatif, Kamar bau dan tidak segar (cendrung bau rokok) tidur jadi tidak nyaman, perbaikan/ service dan maintenance hotel, gidak tersedianya banyak pilihan new makanan.

Berdasarkan penelitian variabel kompetensi pada penelitian yang dilakukan oleh Meri Revita (2017) menjelaskan bahwa kompetensi berpengaruh signifikan terhadap kinerja. Namun sebaliknya penelitian oleh Septiyani (2013) bahwa kompetensi tidak berpengaruh signifikan terhadap Kinerja. Berdasrkan penelitian variabel disiplin kerja pada penelitian oleh Evi Wahyuningsing, Mahlia Muis, Indrianty Sudirman (2013) menemukan bahwa disiplin kerja dapat mempengaruhi kinerja. Namun sebaliknya penelitian oleh Chairul Anam (2018) bahwa disiplin kerja tidak berpengaruh terhadap Kinerja. Berdasarkan penelitian yang dilakukan oleh penelitian Rokhilah dan Susetyo Darmanto (2014) menjelaskan bahwa lingkungan kerja berpengaruh signifikan terhadap kinerja. Namun sebaliknya penelitian oleh (2018) bahwa Indri Tolo, Jantje L.sepang, Lucy O.H Dotuong menjelaskan bahwa lingkungan kerja tidak berpengaruh signifikan terhadap Kinerja.

Dari beberapa hasil peneliti yang berbeda maka peneliti melakukan penelitian dengan judul "Pengaruh Kompetensi, Disiplin Kerja, dan Lingkungan Kerja terhadap Kinerja Karyawan pada Hotel Maharadja".

\section{TINJAUAN PUSTAKA}

Menurut Afandi (2016:69) kinerja adalah sejauh mana seseorang telah memaminkan bagiannya dalam melaksanakan staretegi organisasi, baik dalam mencapai sasaran khusus yang berhubungan dengan peran perorangan dan atau dengan memperlihatkan kompetensi yang di nyatakan relevan bagi organisasi.kinerja adalah suatu konsep yang multi-dimension mencaku dalam tiga aspek yaitu sikap "attitude", Kemampuan "ability" dan prestasi "accomplishment".

Menurut Mc Acshan dalam Sutrisno (2010:203) memberikan pengertian kompetensi sebagai pengetahuan, keterampilan dan kemampuan yang dikuasasi oleh seseoarang yang telah menjadi bagian dari dirinya, sehingga ia dapat melakukan perilaku-perilaku kognitif, efektif, dan psikomotorik dengan sebaik-baiknya. Definisi ini menjelaskan kompetensi diartikan sama dengan kemampuannya, maka dapat diartikan pengetahuan memahami tujuan bekerja, pengetahuan dalam melaksanakan kiat-kiat jitu dalam melaksanakan pekerjaan yang tepat dan baik, serta memahami betapa pentingnya disipling dalam organisasi agar semua aturan dapat berjalam dengan baik. 
Menurut Hasibuan (2014:193) kedisiplinan adalah fungsi operatif keenam dari Manajemen Sumber Daya Manusia. Kedisiplinan merupakan fungsi operatif MSDM yang terpenting karena semakin baik disiplin karyawan, semakin tinggi prestasi kerja yang dapat tercapainya. Tanpa disiplin karyawan yang baik, sulit bagi organisasi perusahaan mencapai hasil yang optimal. Definisi diatas menjelaskan prestasi kerja seorang karyawan dilihat dari tingkat kedisiplinan karyawan tersebut didalam perusahaan.

Menurut Kasmir (2016:192) lingkungan kerja merupakan suasana atau kondisi disekitar lokasi tempat bekerja. Definisi diatas menjelaskan lingkungan kerja dapat berupa ruangan, layout, saran dan prasarana serta hubungan kerja dengan sesame rekan kerja. Jika lingkungan kerja dapat membuat suasana nyaman dan memberikan ketenangan maka akan membuat suasana kerja menjadi kondusif, sehingga dapat meningkatkan hasil kerja seseorang menjadi lebih baik, karena lingkungan tanpa gangguang.

\section{Kerangka Pemikiran}

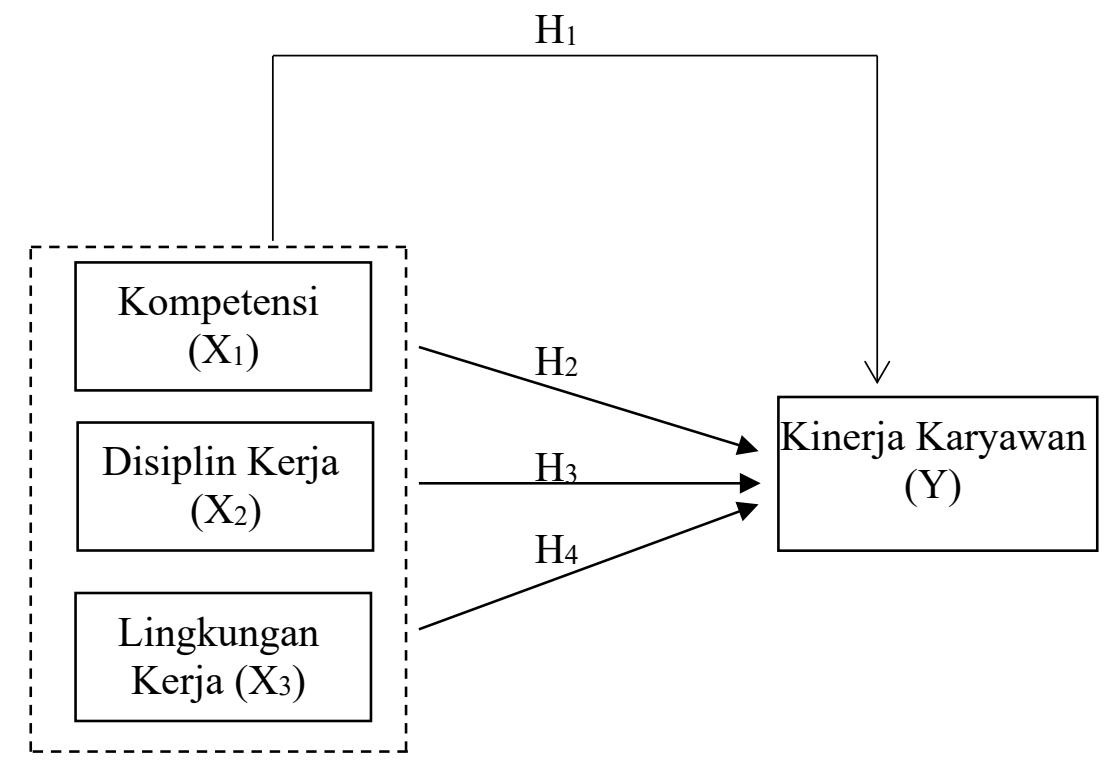

\section{METODOLOGI PENELITIAN}

\section{Populasi dan Sampel}

\section{Populasi}

Populasi adalah keseluruhan subyek penelitian yang mempunyai kesamaan karakteristik tertentu populasi dalam penelitian ini adalah karyawan Hotel Maharadja yang memiliki populasi sebesar 110 karyawan.

\section{Sampel}

Sampel adalah sebagian atau lebih wakil populasi yang diteliti. Sampel dalam penelitian ini adalah jumlah karyawan Hotel Maharadja yaitu karyawan yang berjumlah 110 Orang karyawan. Jenis sample dalam penelitian ini ditentukan dengan sensus, jadi jumlah populasi dan sampel 110 yang layak untuk dianalisis yaitu sejumlah 94 orang karyawan dan tidak kembali atau tidak layak untuk dianalisis sejumlah 16 orang karyawan. 
Metode Analisis Data

\section{Analisis Instrumen Penelitian}

a) Uji Validitas

\begin{tabular}{|c|c|c|c|c|c|}
\hline Variabel & Kode Item & $\mathbf{r}_{\text {hitung }}$ & Kondisi & $\mathbf{r}_{\text {tabel }}$ & Kriteria \\
\hline \multirow{15}{*}{$\begin{array}{c}\text { Kompetensi } \\
\left(\mathbf{X}_{1}\right)\end{array}$} & X1.1 & 0,614 & $>$ & 0,361 & Valid \\
\hline & X1.2 & 0,655 & $>$ & 0,361 & Valid \\
\hline & X1.3 & 0,490 & $>$ & 0,361 & Valid \\
\hline & X1.4 & 0,598 & $>$ & 0,361 & Valid \\
\hline & X1.5 & 0,531 & $>$ & 0,361 & Valid \\
\hline & X1.6 & 0,623 & $>$ & 0,361 & Valid \\
\hline & X1.7 & 0,446 & $>$ & 0,361 & Valid \\
\hline & X1.8 & 0,366 & $>$ & 0,361 & Valid \\
\hline & X1.9 & 0,639 & $>$ & 0,361 & Valid \\
\hline & X1.10 & 0,462 & $>$ & 0,361 & Valid \\
\hline & X1.11 & 0,538 & $>$ & 0,361 & Valid \\
\hline & X1.12 & 0,466 & $>$ & 0,361 & Valid \\
\hline & X1.13 & 0,367 & $>$ & 0,361 & Valid \\
\hline & X1.14 & 0,603 & $>$ & 0,361 & Valid \\
\hline & X1.15 & 0,481 & $>$ & 0,361 & Valid \\
\hline \multirow{18}{*}{$\begin{array}{c}\text { Disiplin } \\
\text { Kerja } \\
\left(\mathbf{X}_{2}\right)\end{array}$} & $\mathrm{X} 2.1$ & 0,376 & $>$ & 0,361 & Valid \\
\hline & $\mathrm{X} 2.2$ & 0,498 & $>$ & 0,361 & Valid \\
\hline & $\mathrm{X} 2.3$ & 0,773 & $>$ & 0,361 & Valid \\
\hline & X2.4 & 0,448 & $>$ & 0,361 & Valid \\
\hline & X2.5 & 0,618 & $>$ & 0,361 & Valid \\
\hline & X2.6 & 0,460 & $>$ & 0,361 & Valid \\
\hline & X2.7 & 0,583 & $>$ & 0,361 & Valid \\
\hline & X2.8 & 0,476 & $>$ & 0,361 & Valid \\
\hline & X2.9 & 0,537 & $>$ & 0,361 & Valid \\
\hline & X2.10 & 0,506 & $>$ & 0,361 & Valid \\
\hline & $\mathrm{X} 2.11$ & 0,741 & $>$ & 0,361 & Valid \\
\hline & X2.12 & 0,644 & $>$ & 0,361 & Valid \\
\hline & X2.13 & 0,464 & $>$ & 0,361 & Valid \\
\hline & X2.14 & 0,518 & $>$ & 0,361 & Valid \\
\hline & X2.15 & 0,488 & $>$ & 0,361 & Valid \\
\hline & X2.16 & 0,602 & $>$ & 0,361 & Valid \\
\hline & X2.17 & 0,519 & $>$ & 0,361 & Valid \\
\hline & X2.18 & 0,580 & $>$ & 0,361 & Valid \\
\hline \multirow{12}{*}{$\begin{array}{c}\text { Lingkungan } \\
\text { Kerja }\left(\mathrm{X}_{3}\right)\end{array}$} & X3.1 & 0,515 & $>$ & 0,361 & Valid \\
\hline & X3.2 & 0,665 & $>$ & 0,361 & Valid \\
\hline & X3.3 & 0,616 & $>$ & 0,361 & Valid \\
\hline & X3.4 & 0,640 & $>$ & 0,361 & Valid \\
\hline & $\mathrm{X} 3.5$ & 0,655 & $>$ & 0,361 & Valid \\
\hline & X3.6 & 0,535 & $>$ & 0,361 & Valid \\
\hline & X3.7 & 0,568 & $>$ & 0,361 & Valid \\
\hline & X3.8 & 0,421 & $>$ & 0,361 & Valid \\
\hline & X3.9 & 0,631 & $>$ & 0,361 & Valid \\
\hline & X3.10 & 0,488 & $>$ & 0,361 & Valid \\
\hline & X3.11 & 0,473 & $>$ & 0,361 & Valid \\
\hline & X3.12 & 0,736 & $>$ & 0,361 & Valid \\
\hline
\end{tabular}




\begin{tabular}{|c|c|c|c|c|c|}
\hline & X3.13 & 0,748 & $>$ & 0,361 & Valid \\
& X3.14 & 0,645 & $>$ & 0,361 & Valid \\
& X3.15 & 0,747 & $>$ & 0,361 & Valid \\
\hline Kinerja & Y.1 & 0,772 & $>$ & 0,361 & Valid \\
Karyawan & Y.2 & 0,762 & $>$ & 0,361 & Valid \\
& Y.3 & 0,707 & $>$ & 0,361 & Valid \\
& Y.4 & 0,817 & $>$ & 0,361 & Valid \\
& Y.5 & 0,651 & $>$ & 0,361 & Valid \\
& Y.6 & 0,597 & $>$ & 0,361 & Valid \\
& Y.7 & 0,807 & $>$ & 0,361 & Valid \\
& Y.8 & 0,672 & $>$ & 0,361 & Valid \\
& Y.9 & 0,671 & $>$ & 0,361 & Valid \\
& Y.10 & 0,609 & $>$ & 0,361 & Valid \\
& Y.11 & 0,707 & $>$ & 0,361 & Valid \\
& Y.12 & 0,858 & $>$ & 0,361 & Valid \\
& Y.13 & 0,875 & $>$ & 0,361 & Valid \\
& Y.14 & 0,550 & $>$ & 0,361 & Valid \\
& Y.15 & 0,447 & $>$ & 0,361 & Valid \\
& Y.16 & 0,661 & $>$ & 0,361 & Valid \\
& Y.17 & 0,544 & $>$ & 0,361 & Valid \\
& Y.18 & 0,538 & $>$ & 0,361 & \\
\hline
\end{tabular}

Uji signifikansi dilakukan dengan membandingkan nilai $\mathrm{r}_{\text {hitung }}$ dengan nilai $\mathrm{r}_{\text {tabel }}$ untuk $(d f)=\mathrm{n}$ - k, dalam hal ini (n) merupakan jumlah sampel dan (k) merupakan jumlah variabel independen. Pada penelitian ini jumlah sampel $(n)=30$, maka besarnya df dapat dihitung 30 $2=28$, dengan $\mathrm{df}=28$ dan alpha $=0,05$ didapat $\mathrm{r}_{\text {tabel }}$ dengan uji dua sisi $=0,361$ (dengan

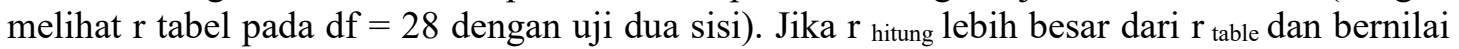
positif, maka butir pernyataan atau indikator tersebut dinyatakan valid.

\section{b) Uji Reliabilitas}

\begin{tabular}{|l|c||l|l||}
\hline \multirow{2}{*}{ Variabel } & \multicolumn{3}{|c|}{ Perbandingan cronbach's alpha } \\
\cline { 2 - 4 } & Cronbach Alpha & $\alpha>\mathbf{6 0 \%}$ & Keterangan \\
\hline Kompetensi $\left(\mathrm{X}_{1}\right)$ & 0,811 & 0,06 & Reliabel \\
Disiplin Kerja $\left(\mathrm{X}_{2}\right)$ & 0,864 & 0,06 & Reliabel \\
Lingkungan kerja $\left(\mathrm{X}_{3)}\right.$ & 0,874 & 0,06 & Reliabel \\
Kinerja Karyawan $(\mathrm{Y})$ & 0,929 & 0,06 & Reliabel \\
\hline
\end{tabular}

Reliabilitas dimaksudkan untuk menunjukkan tentang sifat suatu alat ukur apakah cukup akurat, stabil atau konsisten dalam mengukur apa yang ingin diukur.Perhitungan dilakukan dengan bantuan program SPSS 20.0 for Windows dengan menggunakan metode konsistensi internal melalui teknik analisis varian dari Cronbach's Alpha $(\alpha>60 \%)$. Dari tabel Reliabilitas skala masing-masing konstruk dalam penelitian ini ditunjukkan dengan koefisien Cronbach's alpha sebesar 0,811 untuk Kompetensi, 0,864 untuk Disiplin Kerja, 0,874 untuk Lingkungan Kerja dan 0,929 untuk Kinerja Karyawan. Hasil uji reliabilitas terhadap semua konstruk dalam penelitian ini dapat dilihat dalam Tabel 3.4. Berdasarkan pengujian pada tabel uji reliabilitas diketahui bahwa semua variabel mempunyai Cronbach Alpha>0,06 (60\%) maka dapat disimpulkan bahwa keseluruhan variabel dalam penelitian ini adalah reliable.

c) Analisis Deskriptif

\section{Descriptive Statistics}




\begin{tabular}{|l|r|r|r|r|r|}
\hline & N & Minimum & Maximum & Mean & Std. Deviation \\
\hline X1 & 94 & 50 & 73 & 60.46 & 5.736 \\
X2 & 94 & 51 & 77 & 63.40 & 6.933 \\
X3 & 94 & 42 & 69 & 53.47 & 6.329 \\
Y & 94 & 63 & 85 & 73.60 & 4.725 \\
Valid N (listwise) & 94 & & & & \\
\hline
\end{tabular}

Berdasarkan hasil uji statistic Deskriptif diatas menunujukan dari jumlah responden sebanyak 94 nilai rata - rata kinerja karyawan (Y) dari responden adalah 73,60 dan standart deviasinya 4,72. Sementara itu untuk variable kompetensi (X1) memperoleh nilai rata- rata 60,46 dan standart deviasinya 5,73. Kemudian untuk variable disiplin kerja (X2) memperoleh dengan nilai rata -rata 63,40 dan standart deviasinya 6,93. dan untuk variable ketiga yaitu lingkungan kerja (X3) nilai rata - rata 53,47 dengan standart deviasi 6,32.

\section{Uji Asumsi Klasik}

a) Uji Normalitas

- $\quad$ Metode Kolmogorov-Smirnov

One-Sample Kolmogorov-Smirnov Test

\begin{tabular}{|c|c|c|c|c|c|c|}
\hline & & $\mathrm{X} 1$ & $\mathrm{X} 2$ & $\mathrm{X} 3$ & $\mathrm{Y}$ & $\begin{array}{l}\text { Unstandardiz } \\
\text { ed Residual }\end{array}$ \\
\hline \multicolumn{2}{|l|}{$\mathrm{N}$} & 94 & 94 & 94 & 94 & 94 \\
\hline \multirow[b]{2}{*}{ Normal Parameters ${ }^{\mathrm{a}, \mathrm{b}}$} & Mean & 60.46 & 63.40 & 53.47 & 73.60 & $0 \mathrm{E}-7$ \\
\hline & $\begin{array}{l}\text { Std. } \\
\text { Deviation }\end{array}$ & 5.736 & 6.933 & 6.329 & 4.725 & 2.21487666 \\
\hline \multirow{2}{*}{$\begin{array}{l}\text { Most Extreme } \\
\text { Differences }\end{array}$} & Absolute & .066 & .081 & .091 & .072 & .073 \\
\hline & $\begin{array}{l}\text { Positive } \\
\text { Negative }\end{array}$ & $\begin{array}{r}.066 \\
-.059\end{array}$ & $\begin{array}{r}.071 \\
-.081\end{array}$ & $\begin{array}{r}.091 \\
-.078\end{array}$ & $\begin{array}{r}.071 \\
-.072\end{array}$ & $\begin{array}{r}.073 \\
-.066\end{array}$ \\
\hline \multicolumn{2}{|c|}{ Kolmogorov-Smirnov Z } & .643 & .785 & .885 & .697 & .712 \\
\hline \multicolumn{2}{|l|}{ Asymp. Sig. (2-tailed) } & .803 & .569 & .414 & .716 & .691 \\
\hline
\end{tabular}

a. Test distribution is Normal.

b. Calculated from data.

Dari tabel diperoleh hasil Asymp. Sig. (2-tailed) untuk variabel Kompetensi (X1)= $0,803>0,05$, Disiplin Kerja $(X 2)=0,569>0.05$, Lingkungan Kerja $(X 3)=0,414>0,05$ dan Kinerja Karyawan $(\mathrm{Y})=0,716>0,05$, maka dapat disimpulkan data yang diambil dari populasi terdistribusi normal.

b) Uji Heteroskedastisitas

Hasil Uji Heteroskedastisitas 


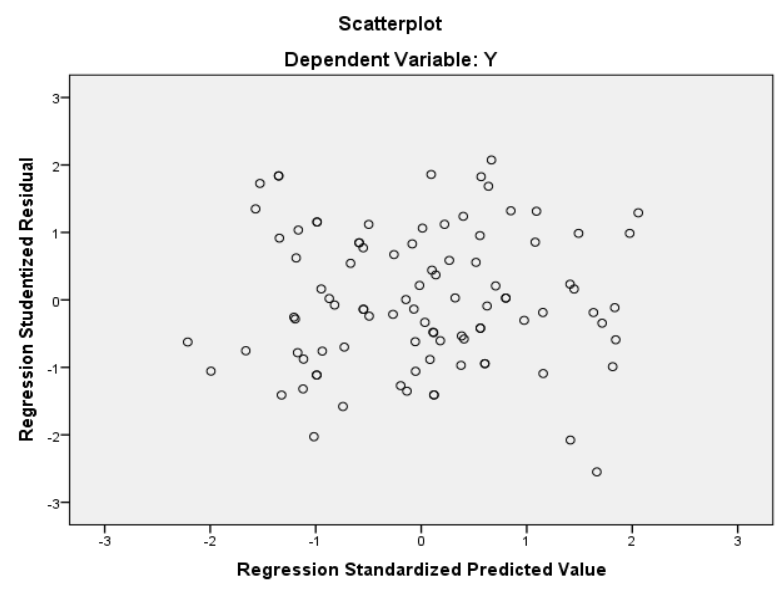

Berdasarkan grafik Uji Heteroskedastisitas pada gambar terlihat titik-titik menyebar secara acak, tidak membentuk pola tertentu dengan jelas, serta tersebar baik diatas maupun dibawah angka 0 (nol) pada sumbu Y, Jadi model regresi yang diajukan dapat dilanjutkan untuk dianalisa karena asumsi klasik yang meliputinya tidak terjadi heteroskedastisitas. Hal ini berarti tidak terjadi heteroskedastisitas pada model regresi sehingga model regresi layak digunakan.

c) Uji Multikolinier

Coefficients $^{2}$
\begin{tabular}{|ll|r|c|}
\hline Model & \multicolumn{2}{c|}{ Collinearity Statistics } \\
\cline { 3 - 4 } & & Tolerance & \multicolumn{1}{c|}{ VIF } \\
\hline \multirow{3}{*}{ (Constant) } & & \\
& X1 & .944 & 1.059 \\
& X2 & .922 & 1.085 \\
& X3 & .873 & 1.146 \\
\hline
\end{tabular}

a. Dependent Variable: $Y$

dari hasil tersebut diketahui bahwa model regresi tidak terjadi gejala multikolinieritas antara variabel-variabel bebas yaiti: kompetensi, disiplin kerja dan lingkungan kerja karena nilai tolerance ketiga variabel tersebut lebih dari 0,1 dan nilai VIF kurang dari 10. Maka peneliti menyimpulkan bahwa tidak terjadi multikolinieritas antar variabel bebas. Dan hasil tersebut dapat dikatakan layak untuk dijadikan pengujian selanjutnya.

d) Uji Autokorelasi

\section{Model Summary ${ }^{b}$}

\begin{tabular}{|l|r|r|r|r|r|}
\hline Mode & $\mathrm{R}$ & R Square & $\begin{array}{c}\text { Adjusted R } \\
\text { Square }\end{array}$ & $\begin{array}{c}\text { Std. Error of } \\
\text { the Estimate }\end{array}$ & $\begin{array}{c}\text { Durbin- } \\
\text { Watson }\end{array}$ \\
\hline 1 & $.883^{\mathrm{a}}$ & .780 & .773 & 2.251 & 2.169 \\
\hline
\end{tabular}

a. Predictors: (Constant), X3, X2, X1

b. Dependent Variable: Y

Berdasarkan hasil output regresi yang ada pada tabel menunjukan bahwa nilai Durbin Watson adalah sebesar 2.169. dengan $\mathrm{n}=94$, dan $\mathrm{k}=3$, didapat nilai $\mathrm{DL}=1,599$ dan nilai $\mathrm{DU}=1,730$ Jadi 
nilai 4-DU $=2.270$ Karena nilai Durbin Watson terletak antara DU dan 4-DU adalah $(1,730<2.169<2.270)$. artinya tidak terjadi autokorelasi pada model regresi.

\section{Analisi Korelasi}

Interprestasi Koefesien Korelasi

\begin{tabular}{|c|c|}
\hline Indeks Korelasi & Penafsiran \\
\hline $0,00-0,199$ & Sangat Rendah \\
\hline $0,20-0,399$ & Rendah \\
\hline $0,40-0,599$ & Sedang \\
\hline $0,60-0,799$ & Kuat \\
\hline $0,80-1,000$ & Sangat Kuat \\
\hline
\end{tabular}

Sumber : Sugiyono (2016:184)

Untuk melakukan pengujinya, kriterianya adalah sebagai berikut :

1. Jika person correlation bernilai positif, maka hubungan yang terjadi searah.

2. Jika person correlation bernilai negative, maka hubungan yang terjadi tidak searah.

Untuk menganalisa korelasi antara variabel kompetensi, disiplin kerja dan lingkungan kerja dapat dilihat dari hasil output SPSS pada tabel 4.16 sebagai berikut :

\begin{tabular}{|c|c|c|c|c|c|}
\hline & & KOMPETENSI & DISIPLIN & LINGKUNGAN & KINERJA \\
\hline & Pearson Correlation & 1 & .076 & $.240^{*}$ & $.802^{* *}$ \\
\hline \multirow[t]{3}{*}{ KOMPETENSI } & Sig. (2-tailed) & & .467 & .020 & .000 \\
\hline & $\mathrm{N}$ & 94 & 94 & 94 & 94 \\
\hline & Pearson Correlation & .076 & 1 & $.278^{* *}$ & $.313^{* *}$ \\
\hline \multirow[t]{3}{*}{ Disiplin } & Sig. (2-tailed) & .467 & & .007 & .002 \\
\hline & $\mathrm{N}$ & 94 & 94 & 94 & 94 \\
\hline & Pearson Correlation & $.240^{*}$ & $.278^{* *}$ & 1 & $.497^{* *}$ \\
\hline \multirow[t]{3}{*}{ LINGKUNGAN } & Sig. (2-tailed) & .020 & .007 & & .000 \\
\hline & $\mathrm{N}$ & 94 & 94 & 94 & 94 \\
\hline & Pearson Correlation & $.802^{* *}$ & $.313^{* *}$ & $.497^{* *}$ & 1 \\
\hline \multirow[t]{2}{*}{ KINERJA } & Sig. (2-tailed) & .000 & .002 & .000 & \\
\hline & $\mathrm{N}$ & 94 & 94 & 94 & 94 \\
\hline
\end{tabular}

*. Correlation is significant at the 0.05 level (2-tailed).

**. Correlation is significant at the 0.01 level (2-tailed).

4. Uji Hipotesis

a) Uji Regresi Linier Berganda

Hasil Uji Regresi Linier Berganda 


\section{Coefficients $^{a}$}

\begin{tabular}{|c|c|c|c|c|c|c|}
\hline \multirow{2}{*}{\multicolumn{2}{|c|}{ Model }} & \multicolumn{2}{|c|}{ Unstandardized Coefficients } & \multirow{2}{*}{$\begin{array}{c}\begin{array}{c}\text { Standardized } \\
\text { Coefficients }\end{array} \\
\text { Beta } \\
\end{array}$} & \multirow[b]{2}{*}{$\mathrm{t}$} & \multirow[b]{2}{*}{ Sig. } \\
\hline & & $\mathrm{B}$ & Std. Error & & & \\
\hline \multirow[t]{4}{*}{1} & (Constant) & 17.659 & 3.327 & & 5.307 & .000 \\
\hline & $\mathrm{X} 1$ & .600 & .042 & .728 & 14.315 & .000 \\
\hline & $\times 2$ & .141 & .035 & .207 & 4.032 & .000 \\
\hline & $\times 3$ & .200 & .039 & .269 & 5.077 & .000 \\
\hline
\end{tabular}

a. Dependent Variable: $Y$

Dari table diatas dapat diabuat persamaan regrsi linear berganda sebagai berikut:

$Y=17,659+0,600 X_{1}+0,141 X_{2}+0,200 X_{3}$

b) Uji Simultan (F)

ANOVAa

\begin{tabular}{|rl|r|r|r|r|r|}
\hline Model & & Sum of Squares & Df & Mean Square & \multicolumn{1}{|c|}{ F } & \multicolumn{1}{c|}{ Sig. } \\
\hline \multirow{2}{*}{1} & Regression & 1620.410 & 3 & 540.137 & 106.553 & $.000^{\mathrm{b}}$ \\
& Residual & 456.228 & 90 & 5.069 & & \\
& Total & 2076.638 & 93 & & & \\
\hline
\end{tabular}

a. Dependent Variable: $Y$

b. Predictors: (Constant), X3, X1, X2

Berdasarkan hasil uji ANNOVA atau F test pada tabel didapetkan Fhitung sebesar 106,533 dengan Ftabel sebesar 2,70 dengan tingkat signifikan 0,000. Karena tingkat signifikan $0,000<0,05$ maka model regresi dapat digunakan untuk memprediksi kinerja karyawan (Y) atau dikatakan bahwa variabel $\mathrm{X} 1, \mathrm{X} 2, \mathrm{X} 3$, secara bersama-sama berpengaruh nyata terhadap variabel Y. Dengan demikian keputusan yang diambil adalah $\mathrm{Ho}_{1}$ ditolak dan menerima $\mathrm{Ha}_{1}$

c) Uji Parcial (t)

\section{Coefficients $^{a}$}

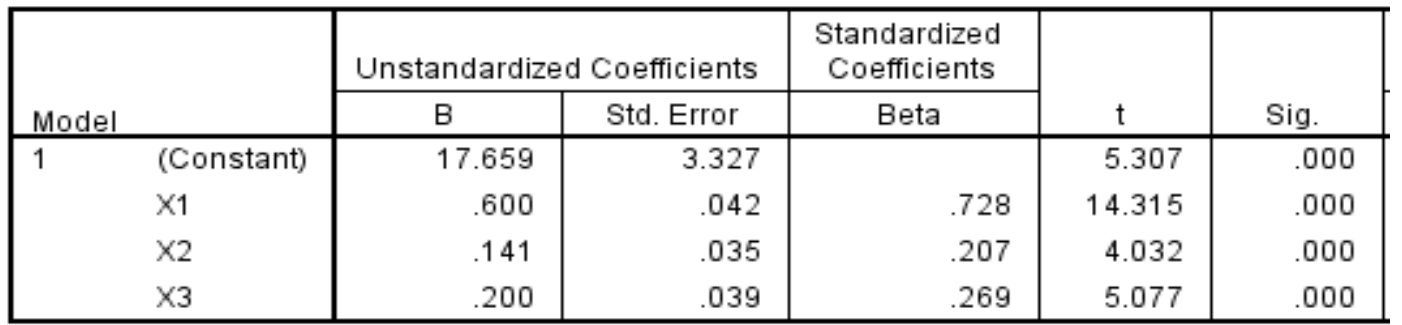

a. Dependent Variable: $Y$

Pengujian Hipotesis 1: terdapat pengaruh positif dan signifikan antara kompetensi terhadap kinerja karyawan. Berdasarkan tabel bahwa thitung $>$ ttabel $14,315>1,985$ dan signifikan $0,000<0,05$ dengan demikian $\mathrm{H}_{01}$ ditolak atau $\mathrm{H}_{a 1}$ diterima, sehingga secara parsial terdapat pengaruh positif dan signifikan antara kompetensi terhadap kinerja karyawan.

Pengujian Hipotesis 2: terdapat pengaruh positif dan signifikan antara disiplin kerja terhadap kinerja karyawan. Berdasarkan tabel bahwa thitung $>$ tabel 4,032 >1,985 dan signifikan $0,000<0,05$ dengan demikian $\mathrm{h}_{02}$ ditolak atau $\mathrm{H}_{\mathrm{a} 2}$ diterima, sehingga secara parsial terdapat pengaruh positif signifikan disiplin kerja terhadap kinerja karyawan.

Pengujian Hipotesis 3: terdapat pengaruh positif dan signifikan antara lingkungan kerja terhadap kinerja karyawan. Berdasarkan tabel bahwa thitung $>$ ttabel 5,007 $>1,985$ dan 
signifikan $0,000<0,05$ dengan demikian $\mathrm{h}_{03}$ ditolak atau $\mathrm{H}_{\mathrm{a} 3}$ diterima, sehingga secara parsial terdapat pengaruh positif dan signifikan lingkungan kerja terhadap kinerja karyawan.

d) Uji Determinasi

Model Summary ${ }^{b}$

\begin{tabular}{|l|r|r|r|r|}
\hline Model & R & R Square & $\begin{array}{c}\text { Adjusted R } \\
\text { Square }\end{array}$ & $\begin{array}{c}\text { Std. Error of } \\
\text { the Estimate }\end{array}$ \\
\hline 1 & $.883^{\mathrm{a}}$ & .780 & .773 & 2.251 \\
\hline
\end{tabular}

a. Predictors: (Constant), X3, X2, X1

b. Dependent Variable: $Y$

Dari Tabel dapat dilhat bahwa nilai Adjusted R Square adalah 0,773 Adjusted R Square disebut juga dengan koefisien determinasi sehingga dalam hal ini berarti 77,3\% menunjukan bahwa persentase sumbangan pengaruh variabel independent (kompetensi, disiplin kerja, dan lingkungan kerja) terhadap variabel dependent (kinerja karyawan). Sedangkan sisanya sebesar $22,7 \%(100 \%-77,3 \%=22,7 \%)$ dipengaruhi atau dijelaskan oleh variabel lain yang tidak dimasukkan dalam penelitian.

\section{PEMBAHASAN}

\section{Pengaruh secara simultan (bersama-sama) antara variabel Kompetensi, Disiplin Kerja dan Lingkungan Kerja terhadap Kinerja.}

Uji F pada dasarnya menunjukan apakah semua variabel bebas Kompetensi (X1), Disiplin Kerja (X2), Lingkungan Kerja (X3) dimasukan dalam model mempunyai pengaruh secara bersama-sama terhadap variabel dependen Kinerja Karyawan (Y). Bahwa Kompetensi, Disiplin Kerja dan Lingkungan Kerja berpengaruh signifikan terhadap Kinerja Karyawan Hotel Maharadja.

Pelatihan ini sejalan dengan penelitian yang dilakukan Santi Ferdiana (2016). Terdapat pengaruh secara bersama-sama (simultan) terhadap kinerja PT.Express Kencana Lestari.

\section{Analisa Kompetensi terhadap Kinerja Karyawan}

Dari hasil penelitian Kompetensi yang dihasilkan pada Hotel Maharadja bahwa Kompetensi memiliki pengaruh signifikan terhadap Kinerja Karyawan. Indikator yang memiliki score terbesar yaitu pada indikator Keterampilan Teknis dan instrument kuesioner yang paling besar mempengaruhi yaitu "karyawan mengerti apa yang diinginkan atasan", dan pada instrumen "menjalankan pekerjaan sesuai dengan prosedur dan peraturan" karyawan sepakat bahwa masih banyak karyawan yang belum menjalankan pekerjaannya sesuai prosedur dan peraturan, karena intrumen memiliki score terendah.

Hal ini sejalan dengan hasil penelitian Meri Revita oleh. Terdapat pengaruh positif dan signifikan Kompetensi Terhadap Kinerja Karyawan Dinas Energi dan Sumber Daya Mineral Kabupaten Sigi.

\section{Analisis Pengaruh Disiplin Kerja Terhadap Kinerja Karyawan}

Dari hasil penelitian yang dihasilkan pada Hotel Maharadja bahwa Disiplin Kerja memiliki pengaruh signifikan terhadap Kinerja Karyawan. Indikator yang memiliki score terbesar yaitu pada indikator membuat laporan harian" dengan intrumen "karyawan mampu membuat laporan harian yang di tugaskan organisasi", dan pada instrument "Dalam bekerja saya tidak mecapai target", mayoritas karyawan sepakat dalam target pekerjaannya masih belum bisa mencapai target pekerjaannya tepat waktu, karena intrumen ini memiliki score terendah. 
Hal ini sejalan dengan hasil penelitian oleh Evi Wahyu ningsih, Mahlia Muis, Indrianty Sudirman. Terdapat Pengaruh positif dan signifikan Disiplin KerjaTerhadap Kinerja Karyawan PT Angkasa Pura I (persero) Bandara Sultan Hasanudin Makassar.

\section{Analisis Pengaruh Lingkungan Kerja Terhadap Kinerja Karyawan}

Dari hasil penelitian Kompetensi yang dihasilkan pada Hotel Maharadja bahwa Lingkungan Kerja memiliki pengaruh signifikan terhadap Kinerja Karyawan. Indikator yang memiliki score terbesar yaitu pada indicator Kebersamaan dengan instrument kuesioner "semua karyawan dapat bersosialisasi dengan baik". Hal ini mengartikan bahwa semua karyawan saling bersosialisai dengan karyawan lainnya tanpa membeda-bedakan status atau jabatannya. Dan pada instrument "Penataan cahaya sangat baik, sehingga tidak mengganggu aktivitas bekerja" memiliki score terendah.

Hal ini sejalan dengan hasil penelitian oleh Rokhilah dan Susetyo Darmanto. Terdapat Pengaruh positif dan signifikan Lingkungan KerjaTerhadap Kinerja penyuluhan lapangan program keluarga berencana (PLKB) di Kabupaten Pemalang.

\section{KSIMPULAN}

Kesimpulan dari hasil pembahasan yang dihasilkan, maka dapat ditarik kesimpulan sebagai berikut:

1. Secara simultan variable Kompetensi, Disiplin Kerja, dan Lingkungan Kerja berpengaruh yang siginifikan terhadap Kinerja Karyawan.

2. Kompetensi memiliki pengaruh yang signifikan terhadap Kinerja karyawan Hotel Maharadja. Indikator tertinggi yaitu indikator Keterampilan Administrative.

3. Disiplin Kerja memiliki pengaruh yang signifikan terhadap Kinerja karyawan Hotel Maharadja. Indikator tertinggi yaitu indikator masuk kerja tepat waktu.

4. Lingkungan Kerja memiliki pengaruh yang signifikan terhadap Kinerja karyawan Hotel Maharadja. Indikator tertinggi yaitu indikator Kebersamaan.

\section{Daftar Pustaka}

Afandi, P. (2016). Concept \& Indicator Of Human Resource Management For Management Research. Edisi 1. Yogyakarta: Deepublish

Nitisemito Alex S. 2014, Manajemen Personalia, Ghalia Indonesia, Jakarta.

Anam Chairul 2014. Pengaruh Motivasi, Kompetensi, Kepemimpinan, Lingkungan Kerja dan Disiplin Kerja terhadap Kinerja Guru di Sekolah Menengah Kejuruan.

Sunyoto, Danang. 2012. Manajemen Sumber Daya Manusia. Jakarta : PT.Buku Seru.

Dessler, Gary. 2015. Manajemen Sumber Daya Manusia. Edisi: 14, Salemba Empat.

Evi, Mahlia dan Indrianty (2013). Pengaruh Motivasi, Disiplin dan Kompetensi terhadap Kinerja Karyawan PT.Angkasa Pura I (PERSERO) Bandara Internasional Sultan Hasanuddin Makassar. Vol : 2 no 1 Juni 2013.

Naja Hasanuddin Rahman Daeng. 2004. Manjemen Fit dan Proper Test, Cetakan pertama, Desember 2004

Imam, Ghozali. 2013. Aplikasi Analisis Multivariate dengan Program SPSS. Edisi Ketujuh. Semarang : Badan Penerbit Universitas Diponegoro.

Imam , Ghozali. (2016). Aplikasi Analisis Multivariete Dengan Program Spss 23.Badan Penerbit Universitas Diponogoro. Semarang

Indri T, Jantje L.S, Lucky O.H.D 2016. Pengaruh keterampilan kerja, disiplin kerja dan lingkungan kerja terhadap kinerja pegawai pada Dinas Pemuda Dan Olahraga (DISPORA) Manado. 
Kasmir 2016. Manjaemen Sumber Daya Manusia (Teori dan Praktik), Rajagrafindo persada Depok

Hasibuan Malayu S.P. 2017. Manajemen Sumber Daya Manusia. Penerbit: Bumi Aksara, Jakarta

Mangkunegara, Prabu, AA. 2011. Manajemen Sumber Daya Manusia Perusahaan. Penerbit : Rosda. Bandung.

Mangkunegara, Prabu, AA. 2012. Evaluasi Kinerja SDM cetakan ke enam. Bandung : Refika Aditama

Mailiana. (2016). Pengaruh disiplin kerja terhadap kinerja pegawai dinas pengelolaan pasar kota bajarmasin', Jurnal Ekonomi Manajemen, Vol. 10, No. 1, 123-134.

Meri Revita (2015). Pengaruh Kompetensi, Disiplin Kerja dan Lingkungan Kerja terhadap Kinerja Pegawai pada Dinas Energidan Sumber Daya Mieral Kabupaten Sigi. Vol : 3 no 9 September 2015.

Moeheriono. 2014. Pengukuran Kinerja Berbasis Kompetensi, Edisi Revisi. Jakarta : Rajawali Pers.

Munparidi (2012). Pengaruh kepemimpinan, motivasi, pelatihan dan lingkungan kerja terhadap kinerja karyawan pada perusahaan Daerah Air Minum Tirta Musi Kota Palembang. ISSN 2085-1375.

Ragil Permasari (2013). Pengaruh motivasi dan lingkungan kerja terhadap kinerja PT. Augrah Raharjo Semarang. ISSN 2252-6552.

Riyanti dan Edison (2016) Pengembangan sumber daya manusia Hotel Grand Panghegar Bandung. Vol 2 no 1 Desember 2016

Rokhilah dan Susetyo (2014). Pengaruh Kompetensi, Motivasi dan LIngkungan Kerja terhadap Kinerja penyuluhan lapanganprogram keluarga berencana (PLKB) di Kabupaten Pemalang. Vol :29 no 1Januari 2019.

Sedarmayanti, M.pd,.APU. 2013. Manajemen sumber daya manusia, cetakan ke 6, Refika Aditama, Bandung

Sugiyono 2016. Metode penelitian Kuantitatif, kualitatif dan $R \& B$. Bandung. PT.Alfabeta

Sedarmayanti. 2013. Manajemen Sumber Daya Manusia, Cetakan Ke 6, Refika Aditama, Bandung.

Srie Wijaya Kusuma Dewi dan Doni Purnama Alamsyah (2017). Hubungan kompetensi, motivasi da kinerja karyawan pada PT.Hutama Karya (Persero) Jakarta. Vol 11, no, 2, Oktober 2017.

Veithzal, Rivai. 2011. Manajemen Sumber Daya Manusia untuk perusahaan : dari teori ke praktek. PT.Raja Grafindo Persada, Jakarta.

Zainul Hidayat dan Muchamad Taufiq (2012). Pengaruh lingkungan kerja dan disiplin kerja serta motivasi kerja terhadap kinerja karyawan perusahaan daerah air minum (PDAM) kabupaten Lumajang. Vol 2. No 1, Maret 2012. 